\title{
Influence of Compressive Strength on Ultimate Strength of Composite Concrete-Steel Girder Subjected to External Prestress
}

\author{
AbdulMutlib I. Said ${ }^{1}$, Larah Riyadh Abdulwahed ${ }^{2}$ \\ ${ }^{1}$ Department of Civil Engineering, College of Engineering, University of Baghdad. Baghdad, Republic of Iraq \\ ${ }^{2}$ PHD Student Structure Engineer, University of Baghdad, Baghdad-Iraq
}

\begin{abstract}
Experimental programmed was carried out to investigate the influence of compressive strength on composite steel I-girder decks subjected to external prestress.This program included fabricating and testing six scale down 1/4, were designed according to AASHTO LRFD 2012 standard specification. Each girder was test as simply supported with span of 3.90m and classified in three groups. The first group consists of two girders for which the concrete strength is 50 MPa. The second group consists of two girders for which the concrete strength is $70 \mathrm{MPa}$. The third group consists of two girders for which the concrete strength is $90 \mathrm{MPa}$. In all groups, the first girder has straight eccentricity without deviator and the second girder have inclined variable eccentricity with deviator at the mid span. The applied loaded incrementally up to failure under the action of two point loads for each increment of load. Vertical deflections were measurement at mid and under point load. The prestressing force in the all girders was (9) Ton applied after the applied of superimposed dead load on RC deck slab. The variables included the compressive strength of concrete, the values of the eccentricity which mean that (location of prestress below bottom face) and with or without deviator.The girders of group (1) showed ultimate load of 210 and 230.The girders of group 2 showed ultimate load of 260 and 280. The girders of group 3 showed ultimate load of 300 and 320. When the compressive strength of concrete is increased from $50 \mathrm{MPa}$ to $90 \mathrm{MPa}$ it causes increased the ultimate load about $42.85 \%$. In general the ultimate load increase by $10 \%$ when the compressive strength increases $10 \mathrm{MPa}$.
\end{abstract}

Keywords: External Prestress, Composite section, Compressive Strength

\section{Introduction}

The research work carried out in strengthening or rehabilitation of existing structures is enormous and covers various types of elements that are commonly used in engineering construction [1] and [2]. External prestressing, initially developed for bridges, is now becoming popular and applicable for a variety of structural systems [3] and [4]. Comparing with an internal prestressing technique, an external prestressing system has the merits of being simpler to construct and easier to inspect and maintain [5]. Choi et al.(2008) [6] tested steel - concrete composite bridge specimens after strengthening them by external prestressing. It was concluded from the test specimens that the increment of a tendon force, which is due to the live load, is approximately $5 \%$ compared to the total amount of a tendon force. Since the total amount of strands can be reduced by considering this increment of a tendon force, a more economical design for strengthening of a bridge may be feasible. Ahmed Q. W. (2011)[7] analyzed four composite beams numerically and the results were compared with those obtained from existing experimental tests. Parametric study was presented to show the effects of the compressive strength of concrete, ratio of effective prestressing stress $f_{p e}$ to ultimate stress $f_{p u}$, effective height to the center of prestressing cables and the type of external prestressing technique. It has been found that, as the compressive strength of concrete increases from $20 \mathrm{MPa}$ to $60 \mathrm{MPa}$ the ultimate load increases by about $18.9 \%$ and for higher value of ratio fpe/fpu (effective prestress to ultimate stress) the ultimate load increases. Increased effective height of tendon has a significant effect on the ultimate strength capacity.

\section{Experimental Program}

\subsection{Fabrication of the models}

The scaled-down factor of (1/4) was adopted for scaling down the model dimensions from a full scale (Prototype).To meet the requirements needed in the experimental, the properties of the model girder section are given in Table 1 considering three different cases. Each of the first, second and third case represents the case of the composite beam action where the steel beam is interconnected to a top reinforced concrete deck slab of 28 days cylinder compressive strength $f c$ of either $50 \mathrm{MPa}$ (Case1) ,70 MPa (case 2) and $90 \mathrm{MPa}$ (Case 3). Each model composite test girder includedSteel beam HEA 160 consist of plate $(160 \mathrm{~mm} \times 9 \mathrm{~mm})$ for top and bottom flange and plate $(134 \mathrm{~mm} \times 6 \mathrm{~mm})$ for web and concrete deck slab of cross section $300 \mathrm{~mm} \times 55 \mathrm{~mm}$ reinforced with welded wire fabric WWF (gauge $150 \mathrm{~mm} \times 150 \mathrm{~mm}$ and $\phi 6 \mathrm{~mm}$ ) and two rows of $\phi 8 \mathrm{~mm}$ diameter studs (height $40 \mathrm{~mm}$ ) spaced $80 \mathrm{~mm}$ in transverse direction and the spaced in the longitudinal direction from the end of the girder are at $50 \mathrm{~mm}$ at $1200 \mathrm{~mm}, 100 \mathrm{~mm}$ at $750 \mathrm{~mm}$ c/c as shown Figure 1 . 


\section{International Journal of Science and Research (IJSR) \\ ISSN (Online): 2319-7064}

Index Copernicus Value (2016): 79.57 | Impact Factor (2015): 6.391

Case I - Composite with $\mathrm{fc}^{\prime}=50, \mathrm{n}=6, \mathrm{E}_{\mathrm{C}}=4700 \sqrt{\mathrm{fc}^{\prime}}$

Table 1: Properties of the Model Girders Equivalent Steel Section

\begin{tabular}{|c|c|c|c|c|c|c|c|}
\hline member & $\begin{array}{l}\text { Size } \\
(\mathrm{mm})\end{array}$ & $\begin{array}{c}\mathrm{A} \\
\left(\mathrm{mm}^{2}\right)\end{array}$ & $\begin{array}{l}\mathrm{Y}_{\mathrm{b}}(\mathrm{mm}) \text { centroid } \\
\text { to bottom }\end{array}$ & $\begin{array}{l}\mathrm{A} \times \mathrm{Y}_{\mathrm{b}} \\
\left(\mathrm{mm}^{3}\right)\end{array}$ & $\begin{array}{c}\mathrm{I}_{0} \\
\left(\mathrm{~mm}^{4}\right)\end{array}$ & $\begin{array}{c}\mathrm{d}(\mathrm{mm}) \\
\text { C.G to NA }\end{array}$ & $\begin{array}{c}\mathrm{Ad}^{2} \\
\left(\mathrm{~mm}^{4}\right)\end{array}$ \\
\hline section HEA160 & & & & & & & \\
\hline Top flange & $160 \times 9$ & 1440 & 147.5 & 212400 & 9720 & 27.26236 & 1070259.937 \\
\hline Web & $6 \times 134$ & 804 & 76 & 61104 & 1203052 & -44.2376 & 1573403.177 \\
\hline Bottom flange & $160 \times 9$ & 1440 & 4.5 & 6480 & 9720 & -115.738 & 19289091.15 \\
\hline $\begin{array}{l}\text { Slab concrete equivalent to steel } \\
300 / \mathrm{n}=50\end{array}$ & $50 \times 55$ & 2750 & 179.5 & 493625 & 693229.2 & 59.26236 & 9658073.882 \\
\hline Summation & & 6434 & & 773609 & 1915721.2 & & 31590828.15 \\
\hline
\end{tabular}

$\overline{Y_{b}}=120.2376 \mathrm{~mm}, \mathrm{I}_{\mathrm{NA}}=33506549 \mathrm{~mm}^{4}$, slab width $=300, n=\frac{E_{s}}{E_{c}}$

Case II - Composite withf $c^{\prime}=70, n=5, E_{C}=4700 \sqrt{f^{\prime}}$

\begin{tabular}{|c|c|c|c|c|c|c|c|}
\hline member & $\begin{array}{c}\text { Size } \\
(\mathrm{mm})\end{array}$ & $\begin{array}{c}\mathrm{A} \\
\left(\mathrm{mm}^{2}\right)\end{array}$ & $\begin{array}{c}\mathrm{Y}_{\mathrm{b}}(\mathrm{mm}) \text { centroid } \\
\text { to bottom }\end{array}$ & $\begin{array}{c}\mathrm{A} \times \mathrm{Y}_{\mathrm{b}} \\
\left(\mathrm{mm}^{3}\right)\end{array}$ & $\begin{array}{c}\mathrm{I}_{\mathrm{o}} \\
\left(\mathrm{mm}^{4}\right)\end{array}$ & $\begin{array}{c}\mathrm{d}(\mathrm{mm}) \\
\text { C.G to NA }\end{array}$ & $\begin{array}{c}\mathrm{Ad}^{2} \\
\left(\mathrm{~mm}^{4}\right)\end{array}$ \\
\hline $\begin{array}{c}\text { section HEA160 } \\
\text { Top flange }\end{array}$ & $160 \times 9$ & 1440 & 147.5 & 212400 & 9720 & 22.59536 & 735192.4764 \\
$\begin{array}{c}\text { Web } \\
\text { Bottom flange }\end{array}$ & $6 \times 134$ & 804 & $\begin{array}{c}76 \\
60 \times 9\end{array}$ & 1440 & 4.5 & 64104 & 1203052 \\
-48.9046 & 9720 & -120.405 & 20876079.07 \\
\hline $\begin{array}{c}\text { Slab concrete equivalent to steel } \\
\text { 300/n=60 }\end{array}$ & $60 \times 55$ & 3300 & 179.5 & 592350 & 831875 & 54.59536 & 9836156.298 \\
\hline Summation & & 6984 & & 872334 & 2054367 & & 3337032549 \\
\hline
\end{tabular}

$\overline{Y_{b}}=124.9046 \mathrm{~mm} \quad, \mathrm{I}_{\mathrm{NA}}=35424692 \mathrm{~mm}^{4}$, slab width $=300, n=\frac{E_{s}}{E_{c}}$

Case III - Composite withfc ${ }^{\prime}=90, \mathrm{n}=4.5, \mathrm{E}_{\mathrm{C}}=4700 \sqrt{\mathrm{fc}}$

\begin{tabular}{|c|c|c|c|c|c|c|c|}
\hline member & $\begin{array}{c}\text { Size } \\
(\mathrm{mm})\end{array}$ & $\begin{array}{c}\mathrm{A} \\
\left(\mathrm{mm}^{2}\right)\end{array}$ & $\begin{array}{c}\mathrm{Y}_{\mathrm{b}}(\mathrm{mm}) \text { centroid } \\
\text { to bottom }\end{array}$ & $\begin{array}{c}\mathrm{A} \times \mathrm{Y}_{\mathrm{b}} \\
\left(\mathrm{mm}^{3}\right)\end{array}$ & $\begin{array}{c}\mathrm{I}_{\mathrm{o}} \\
\left(\mathrm{mm}^{4}\right)\end{array}$ & $\begin{array}{c}\mathrm{d}(\mathrm{mm}) \\
\mathrm{C} . \mathrm{G} \text { to NA }\end{array}$ & $\begin{array}{c}\mathrm{Ad}^{2} \\
\left(\mathrm{~mm}^{4}\right)\end{array}$ \\
\hline $\begin{array}{c}\text { section HEA160 } \\
\text { Top flange }\end{array}$ & $160 \times 9$ & 1440 & 147.5 & 212400 & 9720 & 19.87462 & 568800.568 \\
$\begin{array}{c}\text { Web } \\
\text { Bottom flange }\end{array}$ & $6 \times 134$ & 804 & 76 & 61104 & 1203052 & -51.6254 & 2142804.826 \\
\hline $\begin{array}{c}\text { Slab concrete } \\
\text { equivalent to steel } \\
\text { 300/n=66.6 }\end{array}$ & $66.6 \times 55$ & 1440 & 4.5 & 6480 & 9720 & -123.125 & 21830198.18 \\
\hline Summation & & & 179.5 & 658100.9 & 924213.1 & 51.87462 & 9865925.039 \\
\hline
\end{tabular}

$\overline{Y_{b}}=127.6254 \mathrm{~mm} \quad \mathrm{I}_{\mathrm{NA}}=36554434 \mathrm{~mm}^{4}$, slab width $=300, n=\frac{E_{S}}{E_{c}}$
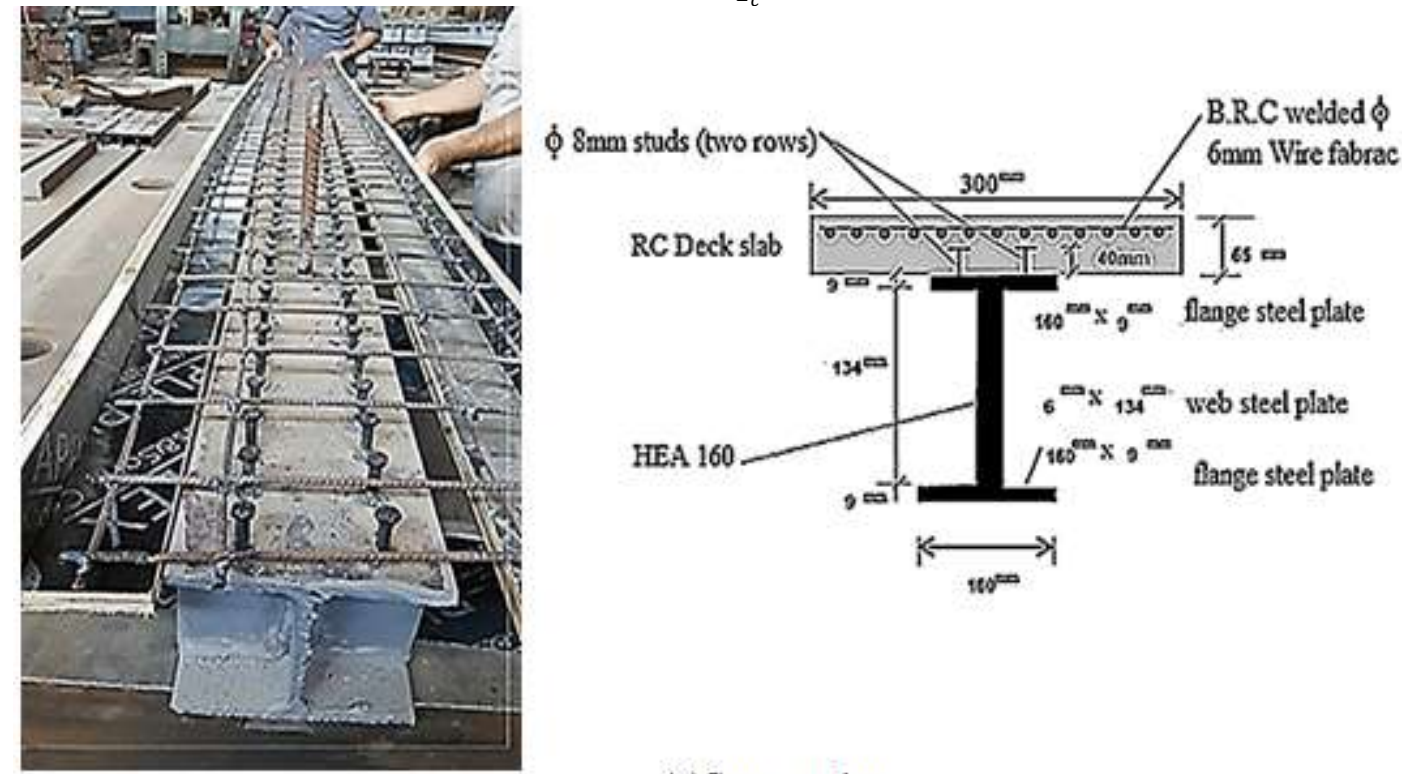

(a)Cross section

Volume 6 Issue 12, December 2017

www.ijsr.net

Licensed Under Creative Commons Attribution CC BY 
International Journal of Science and Research (IJSR)

ISSN (Online): 2319-7064

Index Copernicus Value (2016): 79.57 | Impact Factor (2015): 6.391
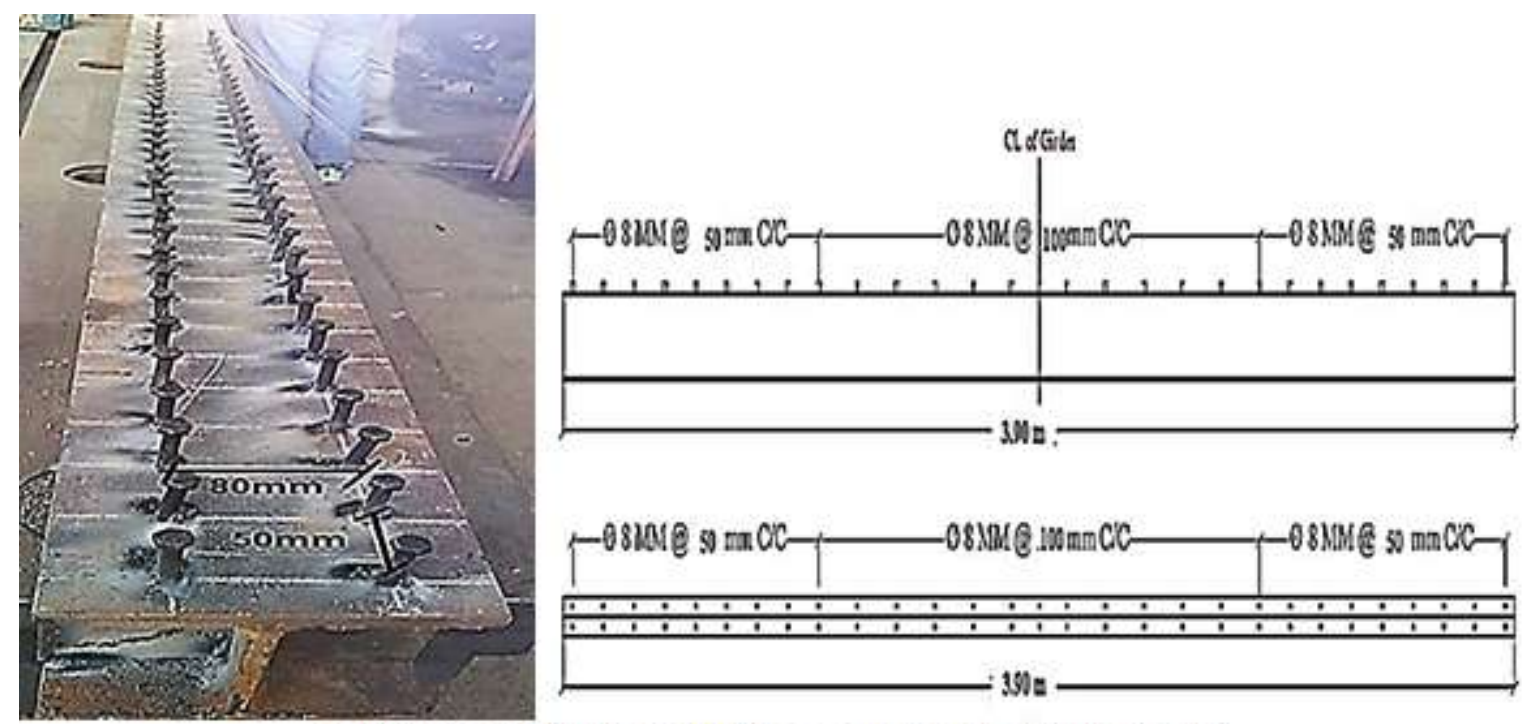

(b) Details and distribution of shear connector for Bridge Model

Figure 1: Model Steel - Concrete Composite Girder Used in Experimental Tests

\subsection{Concrete Mixes}

Three concrete mixes were designed and prepared for constructing the reinforced concrete deck slab of the composite model beams. Mix (1) was normal strength concrete while mix (2) was a high strength concrete and mix (3) was ultra-high compressive strength concrete [8], [9], [10] and [11] . The mix properties of the constituents by weight for these three mixes are listed in Table 2 . The concrete was mixed by using a rotary mixer of $(0.10 \mathrm{~m} 3)$ capacity. The desired amount of silica was mixed with cement amount in dry for five minutes. Then, fine sand is additional to this mix and mixed ten minutes. Then, the required amount of water which is premixed with superplasticizer and added slowly and mixed for 15 minutes. Fiber were distributed into the homogenous mix gradually in five minutes during mixing, and mixing process continued for additional five minutes. In total, the mixing of one batch needs approximately (40) minutes.

Table 2: Properties of the Three Types of Concrete Mixes used in Deck Slab

\begin{tabular}{|c|c|c|c|c|c|c|c|c|c|}
\hline \multirow{2}{*}{ Mix } & Type of concrete & \multicolumn{3}{|c|}{ Mix Properties (kg/m3) } & W/C & Viscocrete 5930*\% & Steel fiber** \% & f'c (MPa) cylinder strength \\
\cline { 3 - 10 } & & Cement & Sand & silica & Water & ratio & & & \\
\hline 1 & Normal strength & 470 & 835 & 23.5 & 164.5 & 0.35 & 1.5 & 0.5 & 50 \\
\hline 2 & High strength & 770 & 1140 & 115.5 & 208 & 0.27 & 3 & 0.5 & 70 \\
\hline 3 & Ultra-high strength & 925 & 1000 & 232 & 222 & 0.24 & 4.5 & 0.5 & 90 \\
\hline
\end{tabular}

*percent of cement weight

**percent of mix volume

\subsection{Load Simulation}

Before the application of the external pre-sterssing on the girders, an important criterion was satisfied to get an exact simulation of the model composite girders with the prototype composite girder. The equivalent loads were applied on the model to induce the same longitudinal bottom steel flange stress as that of the full-scale bridge due to real self-weight and superimposed dead loads. Concrete block $450 \mathrm{~mm} \times 300 \mathrm{~mm} \times 100$ will use as an additional mass to satisfy the simulation requirement of specific gravity loads. The equivalents (self-weight and superimposed equal to $3.2 \mathrm{kN} / \mathrm{m}$ ) are used as addition superimposed dead load which gives the same stress with prototype.

\subsection{Estimation Prestress Force}

Figure 2shows a model of composite beam subjected to externally longitudinal prestressing force applied at a level $80 \mathrm{~mm}$ below its bottom flange face represent the case of straight tendon with constant eccentricity Figure-(2-a) represent the second case when use the deviator at mid span at a level $160 \mathrm{~mm}$ below its bottom flange. Each of these two sections is of $0.45 \mathrm{~m}$ distance away from the nearer support. The maximum value of the applied prestress force $\left(\mathrm{P}_{\mathrm{r}}\right)$ in this case from the allowable stress in concrete at top fiber at mid span of composite beam which is calculated as follows; $\left(\boldsymbol{n} \times \boldsymbol{f}_{t}=-\frac{\boldsymbol{P}_{r}}{\boldsymbol{A}}+\frac{\boldsymbol{P}_{r} \times \boldsymbol{e} \times \boldsymbol{C}}{\boldsymbol{I}}-\frac{\boldsymbol{M} \times \boldsymbol{C}}{\boldsymbol{I}}\right)$. Tensile stress in concrete $\boldsymbol{f}_{\boldsymbol{t}}$ which equal to $0.4 \sqrt{f c}$ was allowed to induce in the concrete and eccentricity $\left(e=80 \mathrm{~mm}+\mathrm{Y}_{\mathrm{b}}{ }^{\prime}\right)$ which lead that the prestress force $\boldsymbol{P}_{\boldsymbol{r}}$ equal to (9 Ton). All the girder contains two brackets for strand anchorage at distance $0.45 \mathrm{~m}$ from supported. Girder (G2, G4 and G6) contains deviator was used at mid span of all strengthened beams.

\section{Volume 6 Issue 12, December 2017}




\section{International Journal of Science and Research (IJSR) \\ ISSN (Online): 2319-7064}

Index Copernicus Value (2016): 79.57 | Impact Factor (2015): 6.391

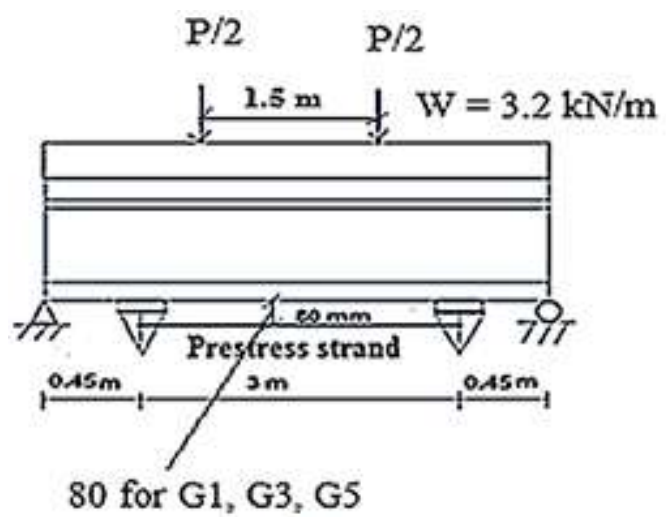

a) without deviator

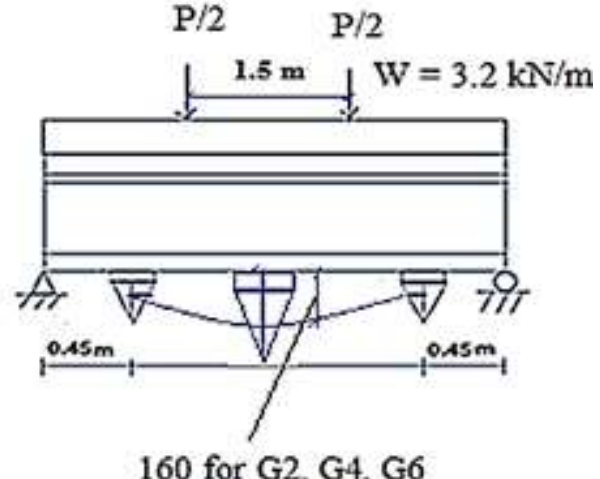

b) with deviator

Figure 2: Location of the External Prestress Tendon

\subsection{Instrumentation and Testing Procedure}

Before testing, the model girder specimen was placed on the supports of the testing machine. Two $30 \mathrm{~mm}$ heavy duty steel rollers were used to support the girders over the clear span and then concrete blocks with dimensions $(450 \mathrm{x}$ $300 \times 100 \mathrm{~mm}$ ) were used to idealize the superimposed dead load of $(3.2 \mathrm{kN} / \mathrm{m})$ with total number of 38 blocks was applied as uniform load on the girder. Thereafter the prestress tendon was post-tensioned to the specified force required for the test as shown in Figure 3.All model girders were tested under static two concentrated point loads. The
(IPN- 400) steel beam used as a rigid be to idealize the two point load case. The jack load was applied at mid-span of rigid beam and then transfer to the two point load. Steel plate $10 \mathrm{~mm}$ thick was used under roller supporting of the rigid beam to avoid the local concrete block failure. The concentrated load was subjected on the test model girder specimen through a jack of the testing machine as shown in Figure 4. After the preparations were finished and the initial readings of the dial gauges were taken, the load was applied with a loading increment rate of about $5 \mathrm{kN}$.
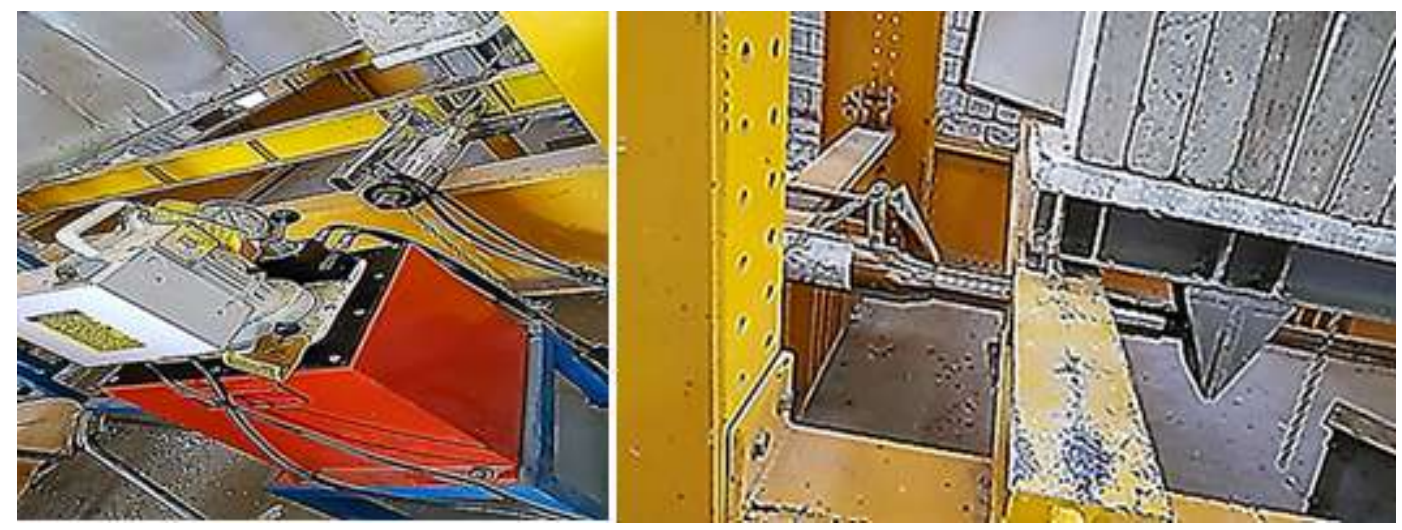

Figure 3: Prestress Post-Tension

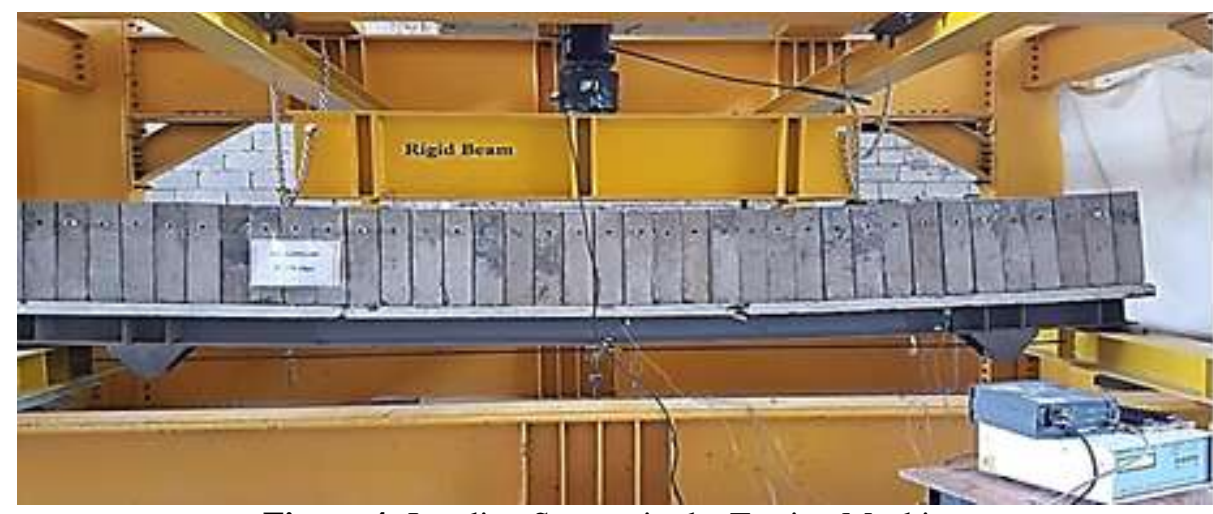

Figure 4: Loading System in the Testing Machine

\section{Results and Discussion}

Table 3 gives a full detailed description of the experimental results for all the tested composite girders models of the present investigation.

Volume 6 Issue 12, December 2017

www.ijsr.net

Licensed Under Creative Commons Attribution CC BY 


\section{International Journal of Science and Research (IJSR) \\ ISSN (Online): 2319-7064}

Index Copernicus Value (2016): 79.57 | Impact Factor (2015): 6.391

Table 3: Experimental Test Results of the Tested Models

\begin{tabular}{|c|c|c|c|c|c|c|c|c|}
\hline Group & Symbol & Designation & $\begin{array}{l}\text { e @ distance } 45 \mathrm{~cm} \\
\text { from end span }\end{array}$ & $\begin{array}{c}\text { e @ mid span by } \\
\text { deviator }\end{array}$ & $\begin{array}{c}f c^{\prime} \\
(\mathrm{MPa})\end{array}$ & $\mathrm{P}(\mathrm{kN})$ & $\begin{array}{c}\Delta \mathrm{u} \text { mid } \\
\operatorname{span}(\mathrm{mm})\end{array}$ & $\begin{array}{c}\Delta \mathrm{u} \text { Under point } \\
\text { load }(\mathrm{mm})\end{array}$ \\
\hline \multirow[b]{2}{*}{1} & G1 & GP9S-e80 & 80 & 80 & \multirow[b]{2}{*}{50} & 210 & 25.43 & 21.44 \\
\hline & G2 & GP9D-e160 & 80 & 160 & & 230 & 26.53 & 22.68 \\
\hline \multirow[b]{2}{*}{2} & G3 & GP9S-e80 & 80 & 80 & \multirow[b]{2}{*}{70} & 260 & 29.87 & 25.81 \\
\hline & G4 & GP9D-e160 & 80 & 160 & & 280 & 33.54 & 29.74 \\
\hline \multirow[b]{2}{*}{3} & G5 & GP9S-e80 & 80 & 80 & \multirow[b]{2}{*}{90} & 300 & 43.04 & 37.42 \\
\hline & G6 & GP9D-e160 & 80 & 160 & & 320 & 48.31 & 40.03 \\
\hline
\end{tabular}

$\mathbf{G}=$ Girder, $\mathbf{P 9}=$ the value of the external prestressing force was 9 Tons, $\mathbf{S}=$ Strand of prestressrepresents as straight line,

$\mathbf{D}=$ Strand of prestressrepresents by deviator

\subsection{Model Girders of Group (1) $\mathrm{fc}^{\prime}=50 \mathrm{MPa}$}

This group consists of the two steel-concrete composite model girders G1and G2 which were designated as GP9S-e80 and GP9D-e160, respectively. Each of which was subjected to an external prestressing force prior to the gradual application of two-point loading up to failure. The external prestressing force was (9 Ton) for these two composite girders; the cylinder compressive strength of the deck slab concrete in all these girders was $\mathrm{fc}^{\prime}=50 \mathrm{MPa}$. Due to the presence of the external post-tensioned prestressing force, these two composite girders of group 1 showed an ability to carry higher ultimate loads with only little increase in vertical deflection. The values of the ultimate load for girders GP9S-e80 and GP9D-e160 were $210 \mathrm{kN}$ and $230 \mathrm{kN}$, respectively corresponding to deflection at mid-span of $25.43 \mathrm{~mm}$ and $26.53 \mathrm{~mm}$ and deflection at under point load of $21.44 \mathrm{~mm}$ and $22.68 \mathrm{~mm}$. The loaddeflection curves for these girders are show in Figure 5 respectively. The two girders of group 1 failed by flexural mode of failure as shown in Figure 6 and 7 respectively.
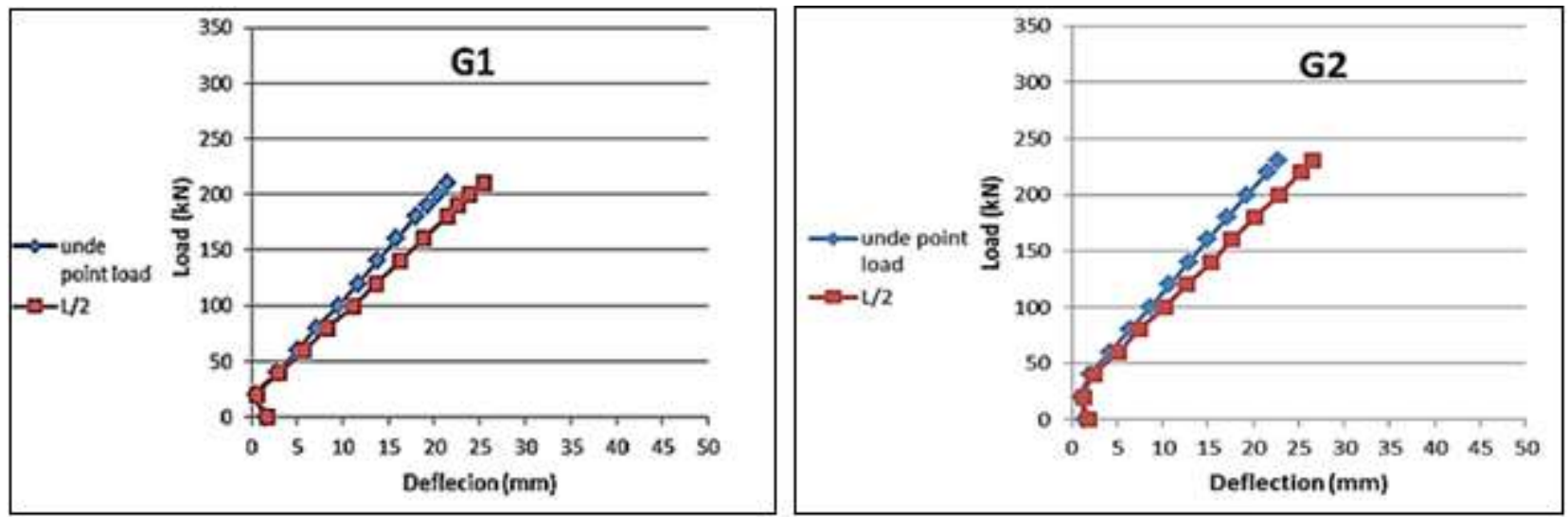

Figure 5: Load-Deflection Behavior of Girder G1 (designated as GP9S-e80) and G2 (designated as GP9D-e160)
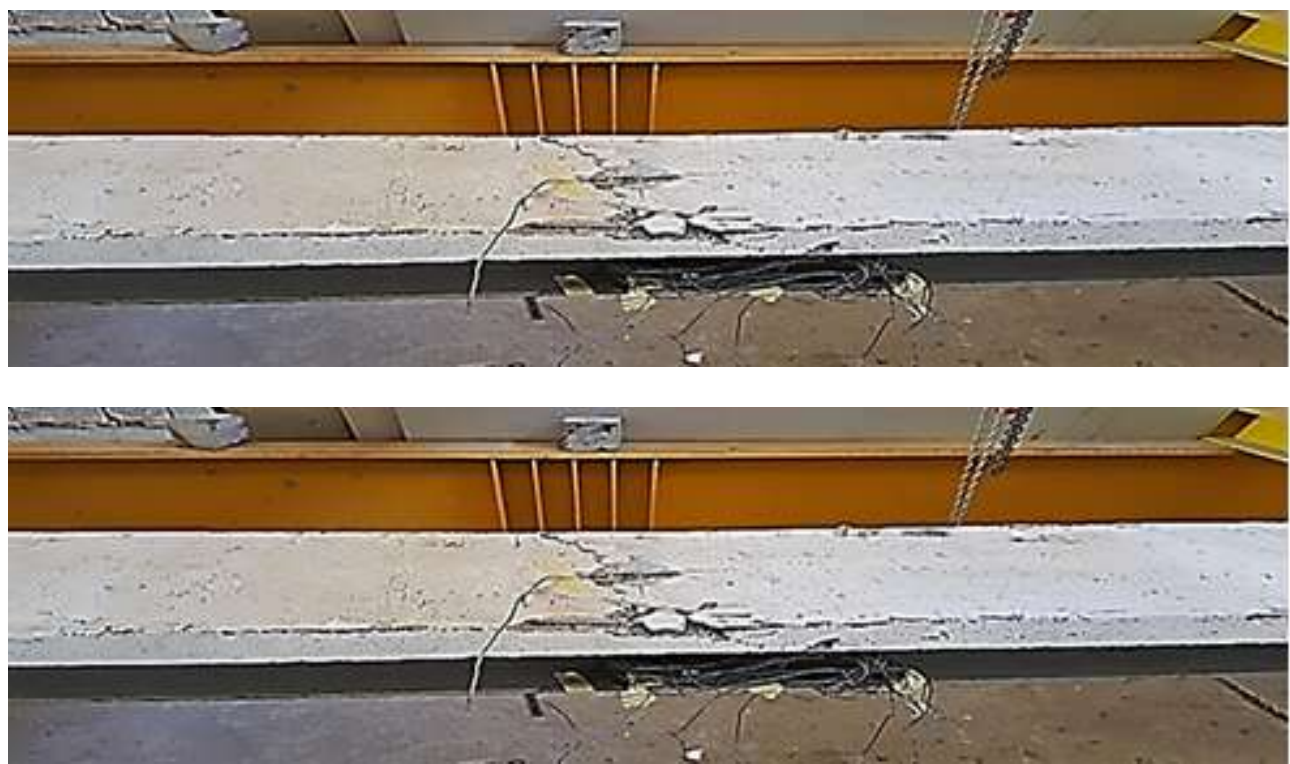

Figure 6: The Mode of Failure of the Steel Girder (GP9S-e80) G1

Volume 6 Issue 12, December 2017 www.ijsr.net

Licensed Under Creative Commons Attribution CC BY 


\section{International Journal of Science and Research (IJSR) \\ ISSN (Online): 2319-7064}

Index Copernicus Value (2016): 79.57 | Impact Factor (2015): 6.391

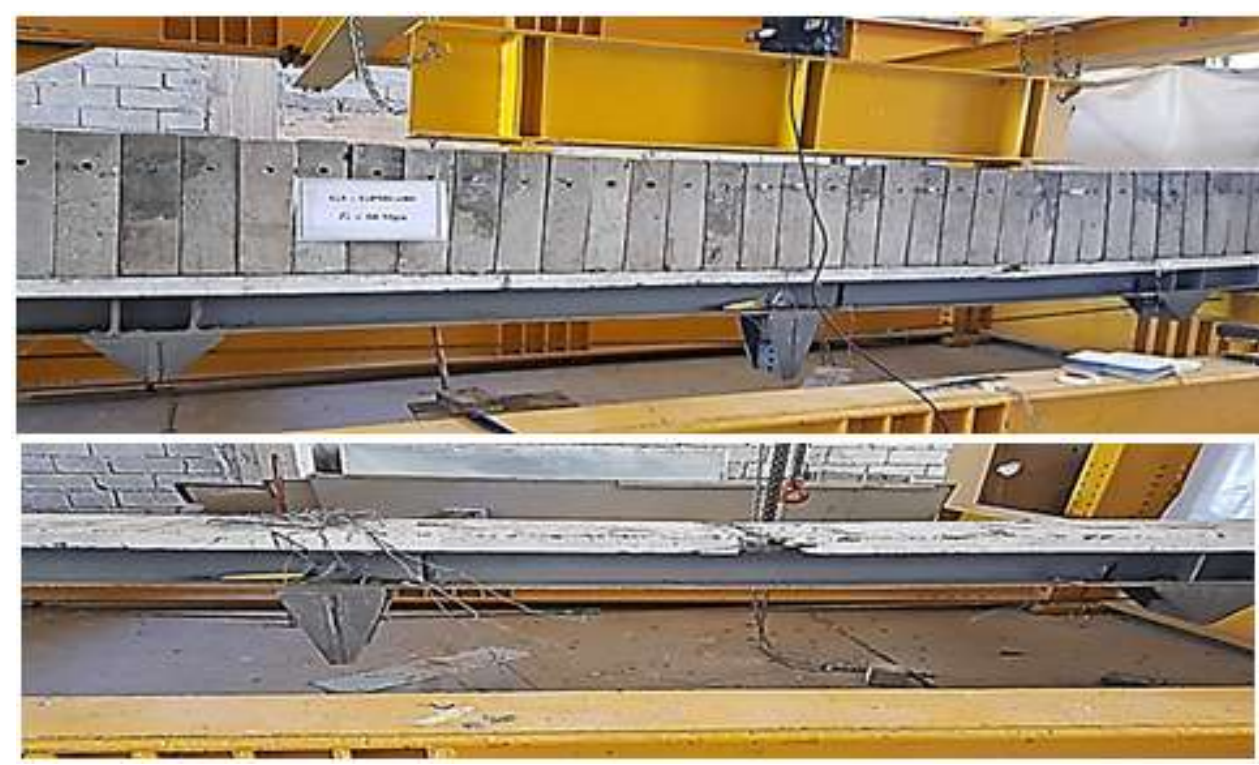

Figure 7: The Mode of Failure of the Steel Girder (GP9D-e160) G2

\subsection{Model Girders of Group (2) fe' $=70 \mathrm{MPa}$}

This group consists of the two steel - concrete composite model girders G3and G4 which were designated as GP9Se80and GP9D-e160 respectively. A high strength concrete was cast to represent the deck slab of these two girders which had a 28 days cylinder compressive strength of value $\mathrm{fc}^{\prime}=70 \mathrm{MPa}$. Prior to the application of two point loading up to failure, each girder was subjected to an external prestressing force. The value of this prestressing force was ( 9 Ton) for the two girders of this group in their respective order. The presence of such external post - tensioned prestressing force and the high strength concrete used for the deck slab increased the flexural strength of the composite model beams of this group remarkably. The values of the ultimate load for girders GP9S-e80and GP9De 160 were respectively $260 \mathrm{kN}$ and $280 \mathrm{kN}$ corresponding to deflections at mid-span of $29.87 \mathrm{mmand} 33.54 \mathrm{~mm}$ and deflections at under point load of $25.81 \mathrm{~mm}$ and $29.74 \mathrm{~mm}$ respectively. The load-deflection curves for these girders are shown in Figure 8 respectively. As the applied load was increased $(2 \mathrm{P}>260 \mathrm{kN})$ in the other specimens for external pre-stress , the state of stress in the steel beam changed from linear to nonlinear and the compressive stress block in the concrete deck slab became inelastic; this can be concluded from the shape of the P- $\Delta$ curve which is showing a noticeable change in shape. When the load approached the peak value, the girder showed rapid increases in the vertical deflection for only small increments in load. The two girders of group 2 failed by flexural mode of failure as shown in Figure 9 and 10 respectively.
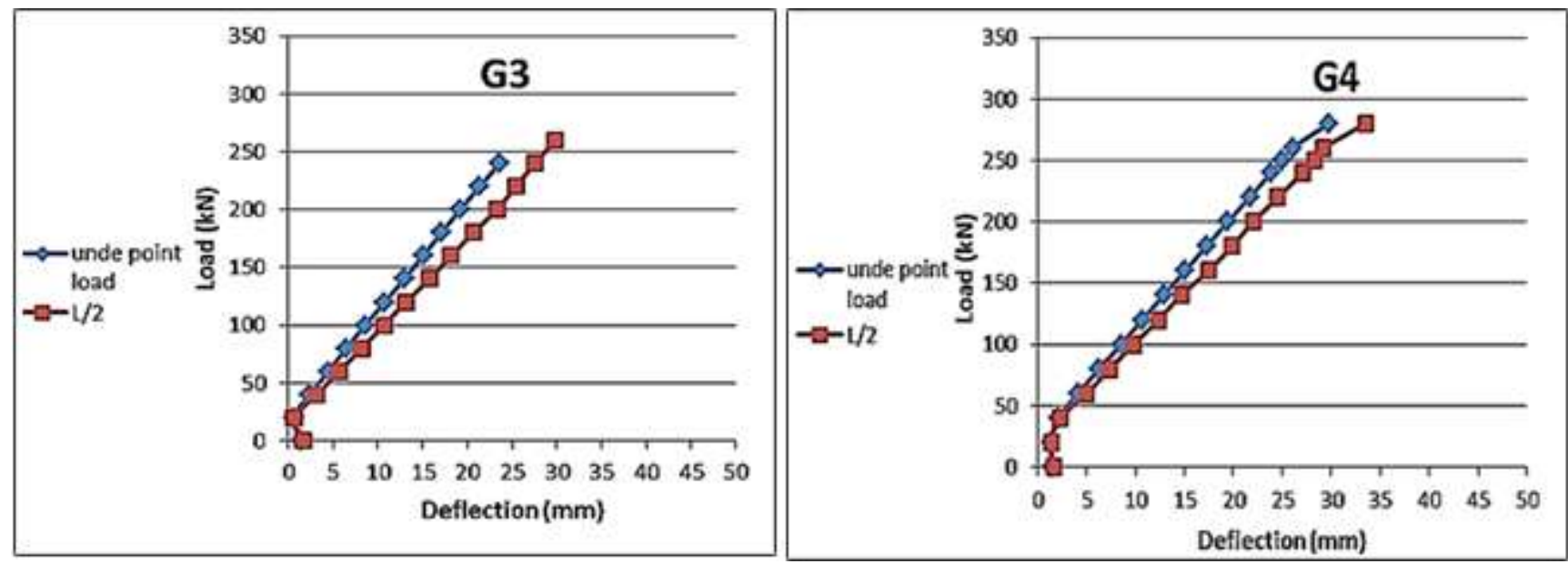

Figure 8: Load-Deflection Behavior of Girder G3 (designated as GP9S-e80) and G4 (designated as GP9D-e160)

Volume 6 Issue 12, December 2017 www.ijsr.net 


\section{International Journal of Science and Research (IJSR) \\ ISSN (Online): 2319-7064}

Index Copernicus Value (2016): 79.57 | Impact Factor (2015): 6.391
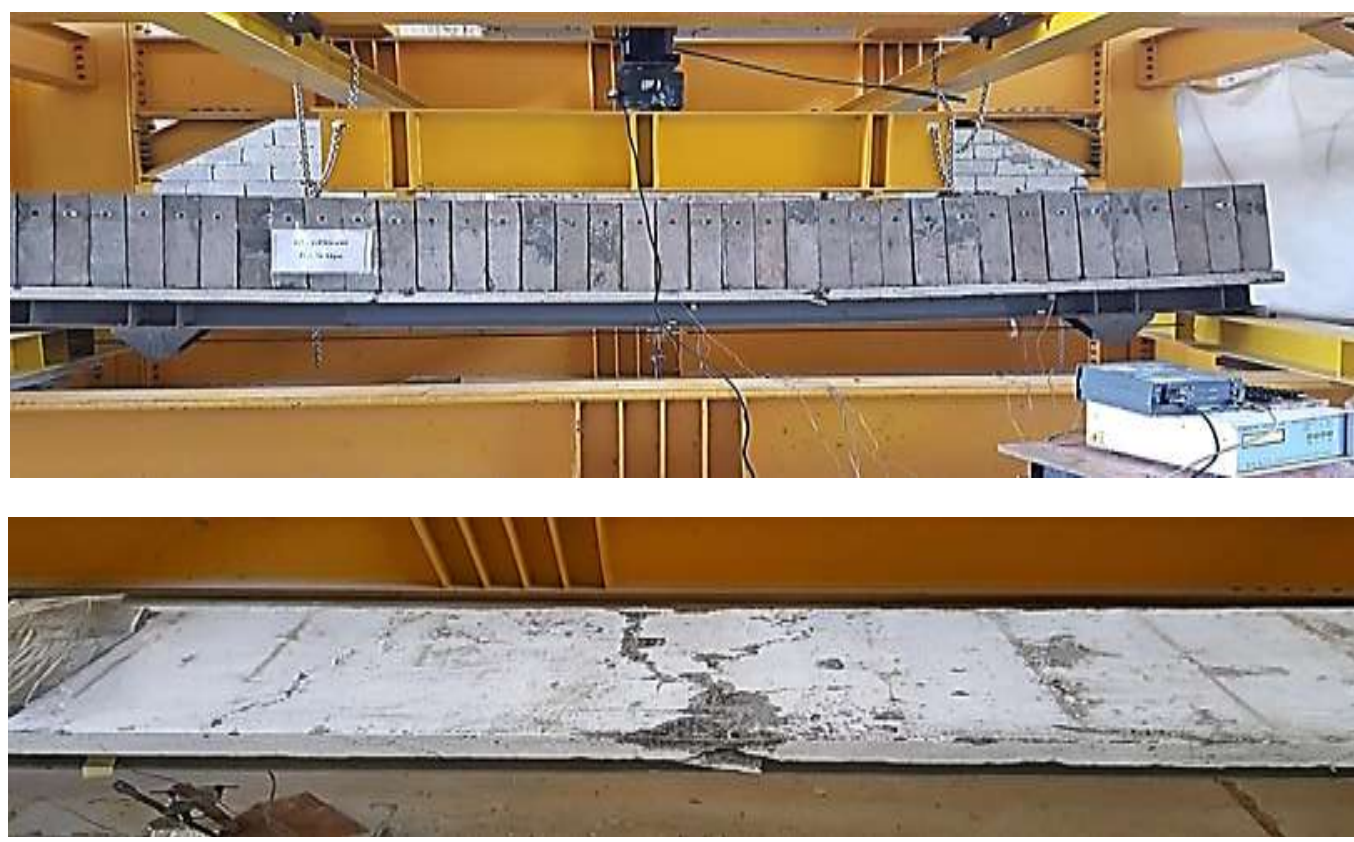

Figure 9: The Mode of Failure of the Steel Girder (GP9S-e80) G3
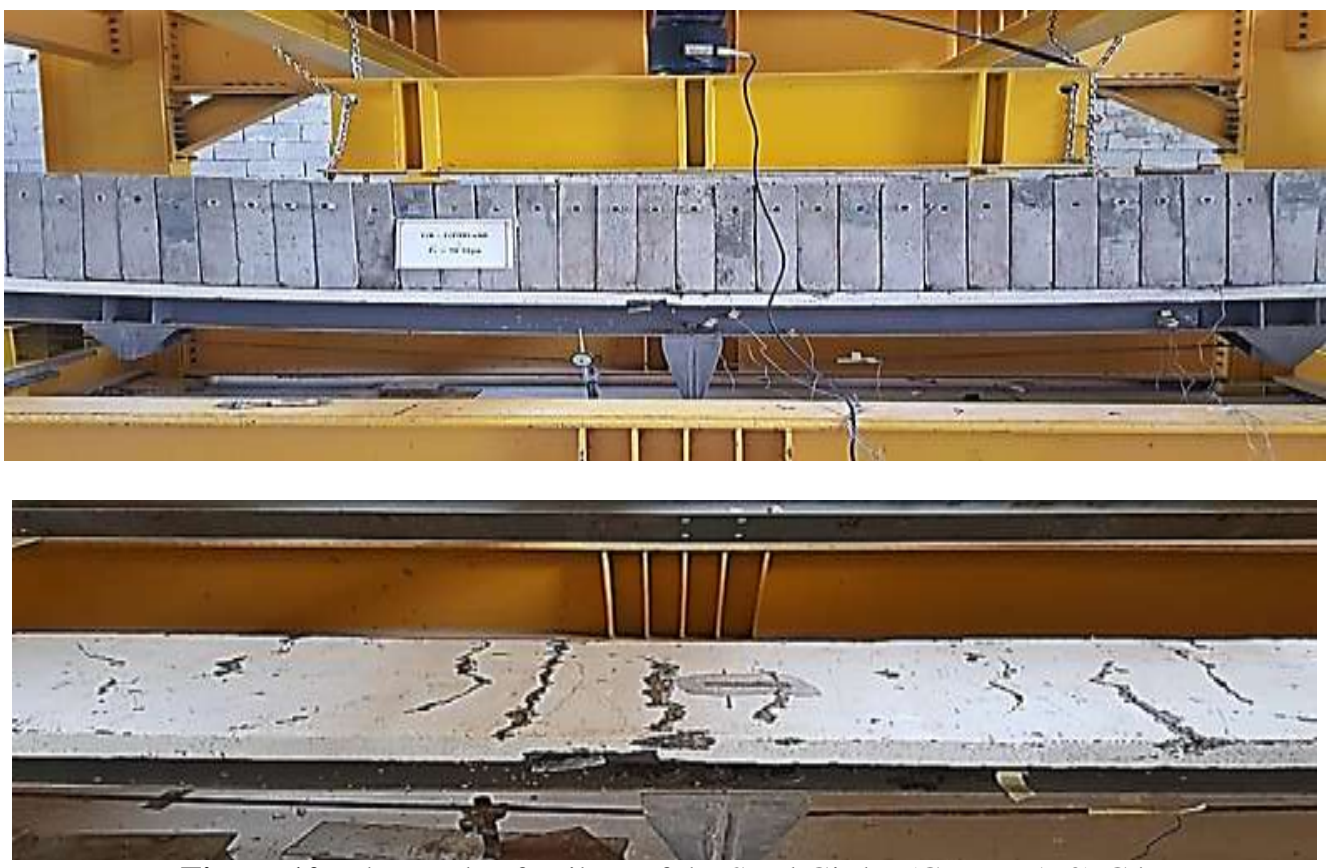

Figure 10: The Mode of Failure of the Steel Girder (GP9D-e160) G4

\subsection{Model Girders of Group (3) $\mathrm{fc}^{\prime}=90 \mathrm{MPa}$}

This group consists of the two steel - concrete composite model girders G5, G6 and which were designated as GP9Se80and GP9D-e160 respectively. Each girder in this group consisted of a steel beam subjected to an external prestressed force of value 9 Ton. The prestressing force was applied after a reinforced concrete deck slab was cast on top and the superimposed dead load is applied. The values of the ultimate two-point loading for girder GP9S- e80 and GP9D-e160 were respectively $300 \mathrm{kN}$ and $320 \mathrm{kN}$ corresponding to deflections at mid-span of $43.04 \mathrm{~mm}$, and $48.31 \mathrm{~mm}$ and deflections at under point load of $37.42 \mathrm{~mm}$ and $40.03 \mathrm{~mm}$ respectively. The load - deflection cures for these girders are shown in Figure 11. The two girders of group 1 failed by flexural mode of failure characterized by full yielding of the steel girder and crushing of the deck slab concrete at mid-span for (G12) and under point load for (G13)as shown in Figure 12 and 13 respectively.

Volume 6 Issue 12, December 2017 www.ijsr.net 
International Journal of Science and Research (IJSR)

ISSN (Online): 2319-7064

Index Copernicus Value (2016): 79.57 | Impact Factor (2015): 6.391

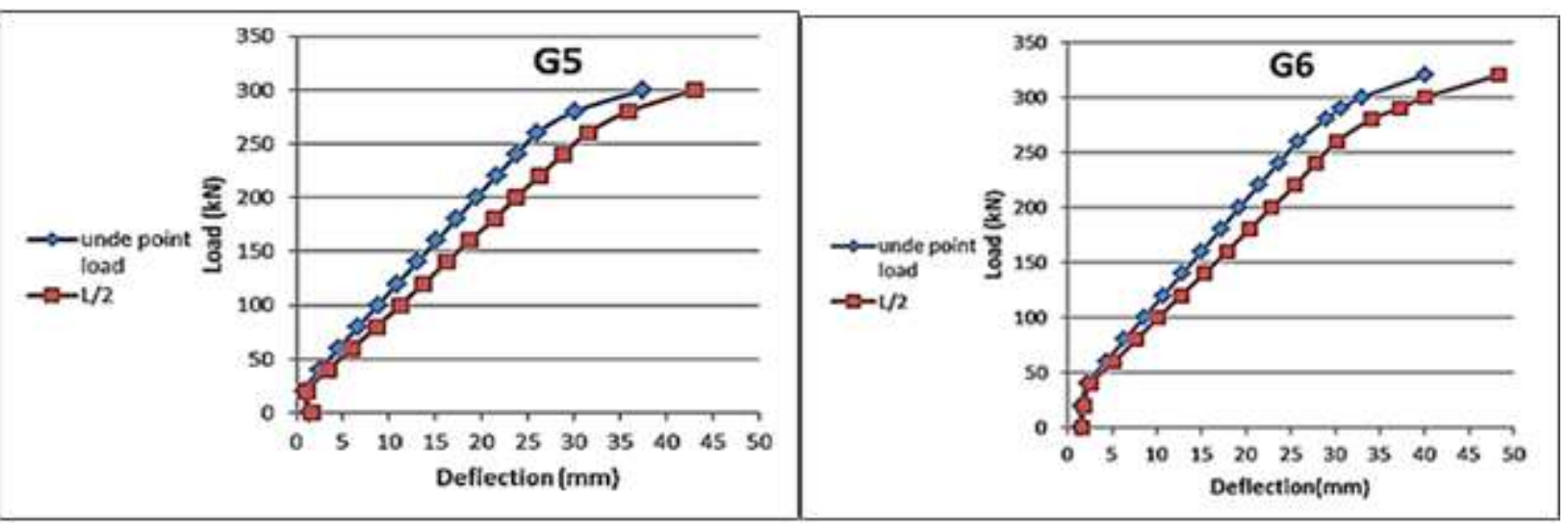

Figure 11: Load-Deflection Behavior of Girder G5 (designated as GP9S-e80) and G6 (designated as GP9D-e160)
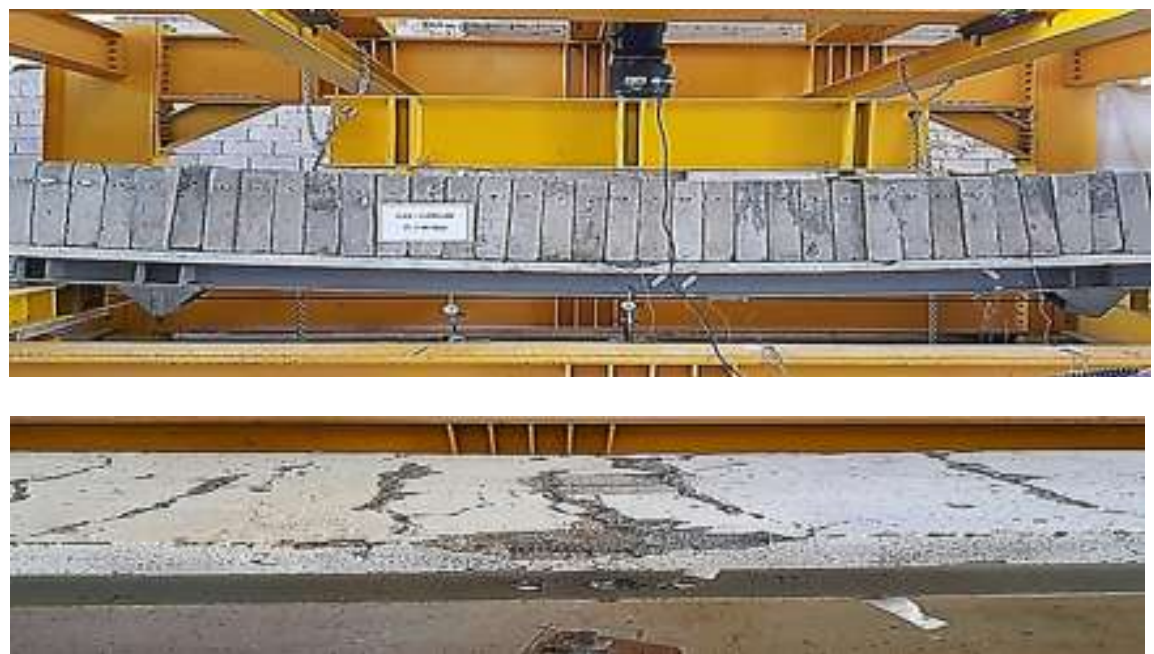

Figure 12:The Mode of Failure of the Steel Girder (GP9S-e80) G5

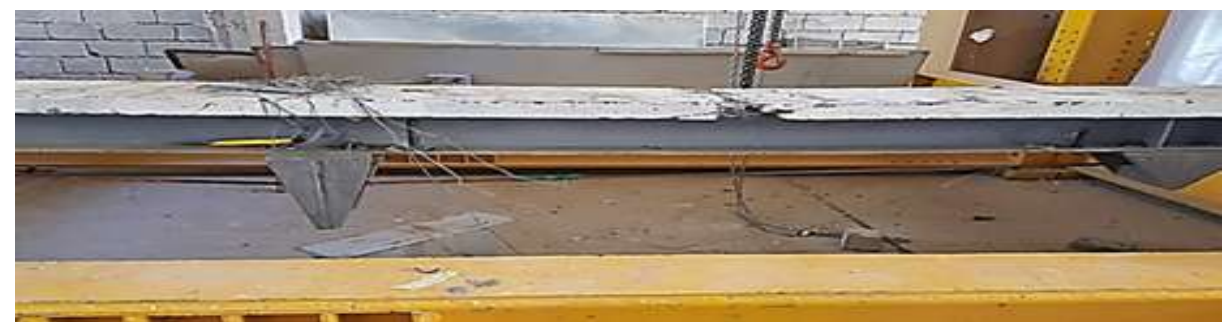

Figure 13: The Mode of Failure of the Steel Girder (GP9D-e160) G6

\subsection{Compressions between Groups}

To stand on the actual enhancement in the load carrying capacity of composite steel-concrete girders caused by the increase in the compressive strength of the deck slab concrete alone, the ultimate loads of the girder G1 are to be compared with their corresponding values of the girder G3 and G5 straight shape of strand and G2 are compared with G4 and G6 strand with deviator at mid span as shown Figure 14.
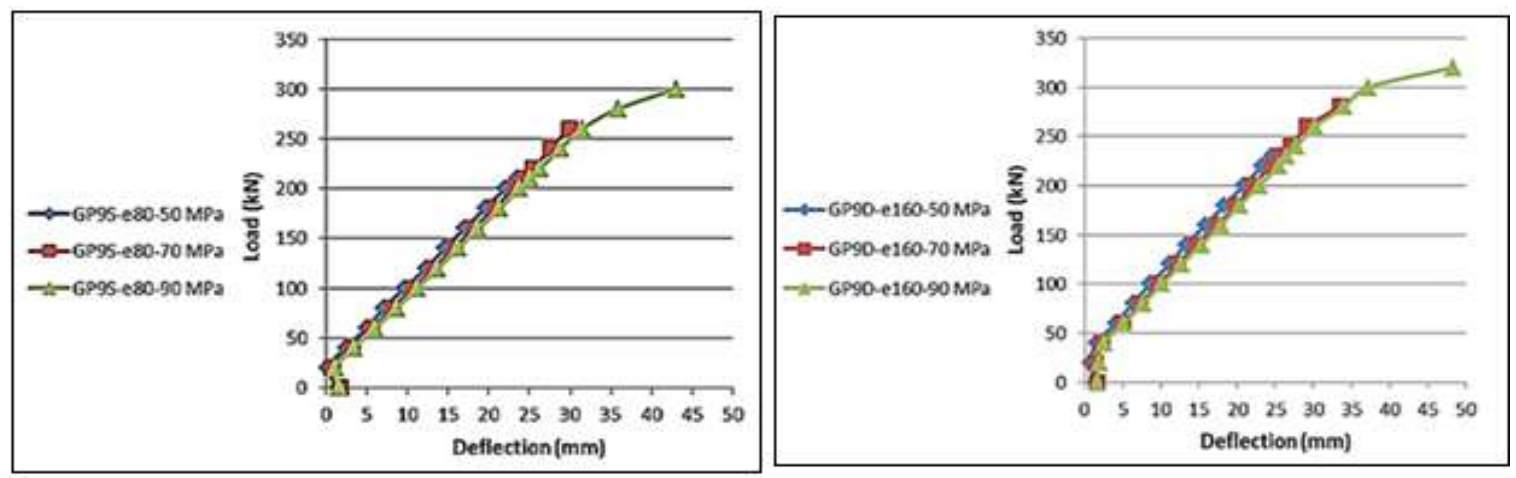

Figure 14: Comparison of these 6 Load-Deflection Curves with Different Compres-sive Strength (50, 70, and 90) MPa

\title{
Volume 6 Issue 12, December 2017
}

\author{
www.ijsr.net
}

Licensed Under Creative Commons Attribution CC BY 


\section{International Journal of Science and Research (IJSR) \\ ISSN (Online): 2319-7064}

Index Copernicus Value (2016): 79.57 | Impact Factor (2015): 6.391

It can be seen from Table 4 that the enhancement in ultimate load caused by the increase in the value of fc' from $50 \mathrm{MPa}$ to $90 \mathrm{MPa}$. From the value of percentage increase of ultimate load, one can conclude that the percentage increases are equal to different between the values of reference compressive strength and other compressive strength i.e. when the compressive strength increase by $10 \mathrm{MPa}$ the percentage increase in percentage of ultimate load equal to $10 \%$.Figure 15 is plotted to show clearly that the effect of fc' on ultimate load.

Table 4:Comparison of these Percentage Increase in Ultimate Load

\begin{tabular}{|c|c|c|c|c|c|c|}
\hline Symbol & Designation & $\begin{array}{c}\mathrm{fc}^{\prime} \\
(\mathrm{MPa})\end{array}$ & $\begin{array}{c}\mathrm{P} \\
\mathrm{kN}\end{array}$ & $\begin{array}{c}\text { \% increase } \\
\mathrm{In}(\mathrm{P})\end{array}$ & $\begin{array}{c}\text { Pu 70 or 90 } \\
\text { Pu 50 }\end{array}$ & $\begin{array}{c}\text { P with deviator } \\
\text { Pithout deviator }\end{array}$ \\
\hline G1 & GP9S-e80 & 50 & 210 & Reference & - & Reference \\
\hline G3 & GP9S-e80 & 70 & 260 & $23.80 \%$ & 1.238 & Reference \\
\hline G5 & GP9S-e80 & 90 & 300 & $42.85 \%$ & 1.428 & Reference \\
\hline G2 & GPD-e160 & 50 & 230 & Reference & - & 1.095 \\
\hline G4 & GP9D-e160 & 70 & 280 & $21.73 \%$ & 1.217 & 1.077 \\
\hline G6 & GP9D-e160 & 90 & 320 & $39.13 \%$ & 1.391 & 1.067 \\
\hline
\end{tabular}

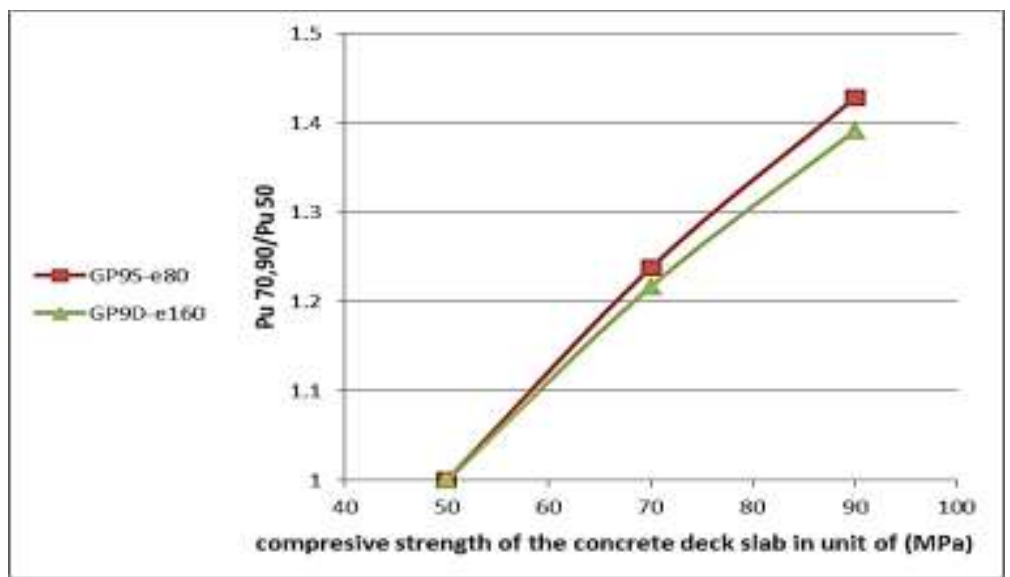

Figure 15: Effect of the Compressive Strength fc' of the Concrete deck Slab in Composite Steel- Concrete girders

\section{Conclusion}

1-From the experimental carried out to study the effect of compressive strength of concrete on the strength behavior, it was found that as the compressive strength of concrete is increased from $50 \mathrm{MPa}$ to $90 \mathrm{MPa}$ the ultimate load capacity is increased by about $42.85 \%$ from $50 \mathrm{MPa}$ to $70 \mathrm{MPa}$ the ultimate load increase by $23.80 \%$.

2-To stand on the actual enhancement in ultimate loads of composite girders due to using higher strength concrete for the deck slab only (i.e by keeping the other parameters including the amount of external prestressing force constant and eccentricity), the girders of group 1 were compared with their corresponding girders of group 2 and group 3 that had the ultimate load increase by $10 \%$ when the compressive strength increases $10 \mathrm{MPa}$

3-Strengthening only part of the composite girder span was proved to enhance the strength of prestressed. The performance and procedure of strengthening and prestressing of girder was found to be effective and of remarkable effects since partial span prestressing technique in strengthening can provide a space between the supports and anchors system as a free area for fixing and jacking.

4-To stand on the actual enhancement in ultimate loads of composite girders caused by changing only the sequence of applying the external prestress force (whether with or without the deviator), while keeping the other parameters constant including the amount of the external prestress force and the compressive strength of the RC deck slab, the girders (GP9S-e80-50MPa, GP9S-e80-70MPa, ,GP9S-e80$90 \mathrm{MPa}$ ) were compared with their corresponding girders (GP9D-e160-50MPa, GP9D-e160-70MPa, GP9D-e160$90 \mathrm{MPa})$. Results of such comparison showed that the ultimate load due to applying the external prestress force with deviator represent $(230,280$ and 320) respectively higher than those whose have strength external prestress force without deviator represent (210, 260 and 300) respectively.

5-The simply supported externally prestressed girders, which were tested up to failure shows high stiffness at early stage of loading represented by initial steep curve of the load-deflection behavior with elastic stresses in both the steel I-beam and RC deck slab. When the applied load was increased, the state of stress in the steel beam changed from elastic to elastic-plastic and the compressive stress block in the RC deck slab became inelastic. This was concluded from the shape of the P- $\Delta$ curve which showed a noticeable reduction in slope during this stage of loading. When the load approached the peak value, the beam showed rapid increases in the vertical deflection for only small increments in load. At ultimate load, the concrete of the deck slab crushed at mid-span and the whole steel I-beam reached the fully plastic condition indicating a sign of flexural failure.

\section{Reference}

[1] Daly F. , Witarnawan W. " Strengthening of Bridges Using External Post-Tensioning" Conference of Eastern

\section{Volume 6 Issue 12, December 2017}




\section{International Journal of Science and Research (IJSR) \\ ISSN (Online): 2319-7064}

Index Copernicus Value (2016): 79.57 | Impact Factor (2015): 6.391

Asia Society for Transportation Studies, Seoul, Korea, October ,1997.

[2] AbdulMuttalibI.Said, Ali Hussein Ali AL-Ahmed and Dhafer AL-Fendawy "Strengthening of Reinforced Concrete T- Section Beams Using External PostTensioning Technique". Journal of Engineering, Vol.21, No 12, December 2015, pp. 139-154

[3] Saadatmanesh H., Albrecht P., and Ayyub B. " Guidelines for Flexural Design of Prestressed Composite Beams " Journal of Structural Engineering, ASCE , Vol. 115, No. 11, November, 1989, pp.29442961.

[4] AbdulMuttalibI.Said, Ali Hussein Ali AL-Ahmed and Dhafer AL-Fendawy "Strengthening Behavior of Reinforced Concrete T- Beams Using External PrestressTendons".Applied Research Jornal, Vol.2, No 11, November 2016

[5] HåkanNordin, "Strengthening structures with externally prestressed tendons", 1402-1536 - ISRN: LTU-TR-05/06-SE, 2005.

[6] Choi D., Kim Y., and Yoo H. "External PostTensioning of Composite Bridges by a Rating Equation Considering the Increment of a tendon Force Due to Live Loads". Steel Structures, Vol. 8, June 2008, pp. 109-118.

[7] Ahmed Q. W. "Behavior of Composite Steel-Concrete Beams with External Prestressing". M.Sc. Thesis, AlMustanisiriya University, Iraq, 2011.

[8] Maleka N.N. , A.A.Bashandy and M.A.Arab (2014) ,Behavior and Analysis of Economically Reactive Powder RC Beams ", Asian journal of civil engineering (BHRC), Vol.15,No.5.

[9] Pierre Richard and Marcel Cheyrezy, "Composition of reactive powder concretes," Cement and Concrete Research, Vol. 25. No. 7, pp. 1501-1511, 1995.

[10]Richard, P. and Cheyrezy, M., "Reactive Powder Concrete with High Ductility and 200-800 MPa Compressive Strength", ACI SP144-24, 1994, pp. 507518.

[11] Collepardi, S., Coppola, R., Troli, R. and Zaffaroni, P., "Influence of the Superplasticizer Type on the Compressive Strength of Reactive Powder Concrete for Precast Structures", Congress International BIBM, Venzia, Maggi o 25-28, 1999, pp. 25-30

Volume 6 Issue 12, December 2017 www.ijsr.net 